\title{
INTERNATIONAL RESCUE COMMITTEE
}

REHABILITATION PROGRAMME FOR

\author{
AFGHANISTAN
}

\section{AND}

\section{LANDMINE CLEARANCE}

BY JANE THOMAS, PESHAWAR

SEPT-OCT. 1992

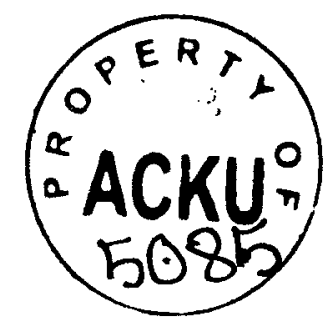




\title{
INTERNATIONAL RESCUE COMMITTEE
}

REHABILITATION PROGRAMME FOR

\author{
AFGHANISTAN
}

\author{
AND
}

LANDMINE CLEARANCE

BY JANE THOMAS, PESHAWAR

SEPT-OCT. 1992 
IRC/RPA and Landmine clearance

CONTENTS

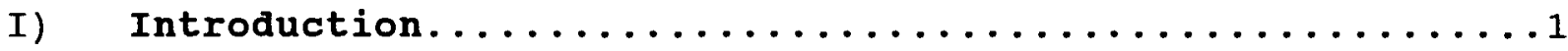

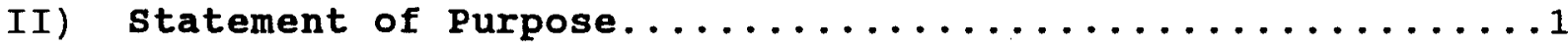

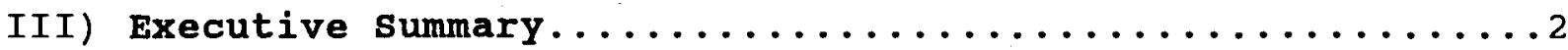

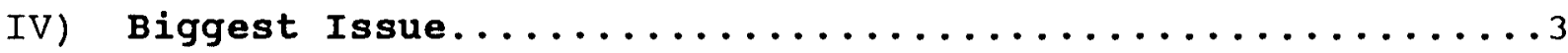

V) Recommended options.......................

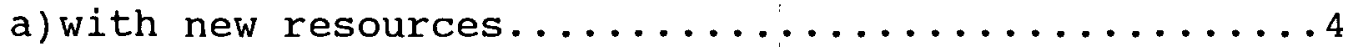

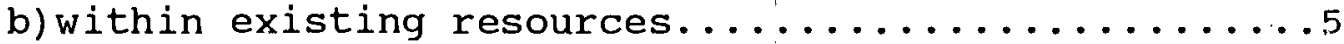

c) options considered but not recommended..........9

VI) Background: Independent Evaluation...............10

VII) Who's Who, who Does, What, and How?..............

a) "UNOCA"/"Operation Salaam".................. 12

i) name

ii) organizational structure

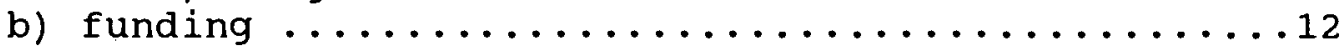

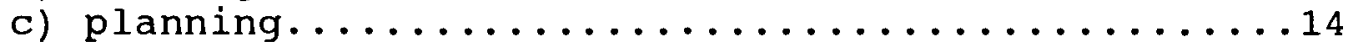

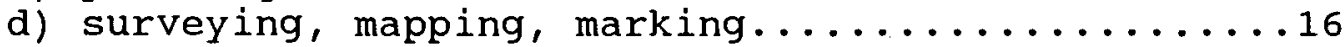

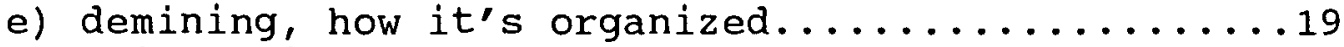

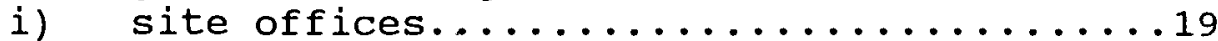

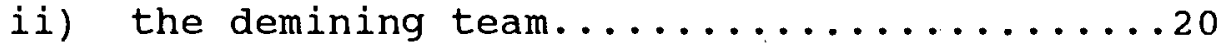

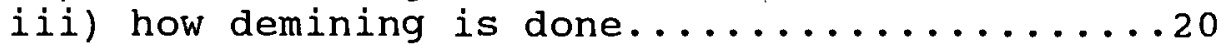

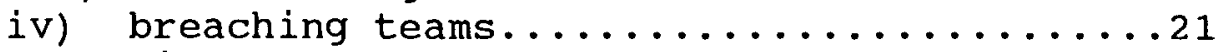

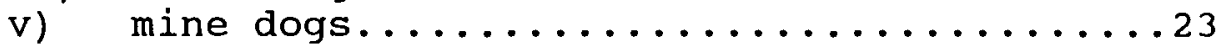

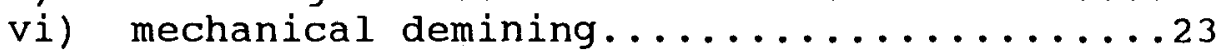

vii) new machines being looked at..........24

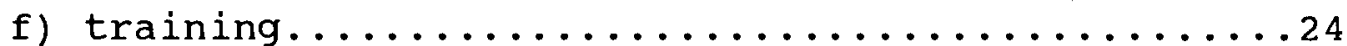

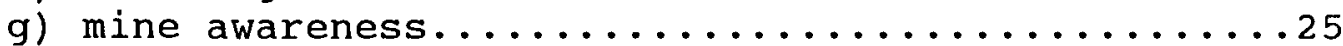

h) role of foreign military personnel..........27

VIII) What's Been Surveyed and Demined and What's Planned....28

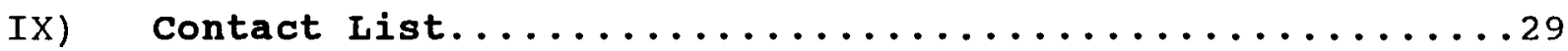




\section{List of Documents Included}

Annex

1. parameters of study

2. selection of priority areas for demining

3. Evaluation of Mine Clearance Programme

4. (UNOCA's official) response to the above evaluation

5. (one NGOs response to above evaluation) "Comments on...

6. MCPA map samples

7. ATC demining tasks monthly progress report

8. MCPA 1991 map indicating areas surveyed

9. graphs showing areas surveyed and cleared by province

10. computer print-out showing surveyed and cleared areas in Ningrahar, Paktika and Paktia

11. Operations plan, Aug-Dec. 1992

12. Mid-Year Report, Jan-June, 1992 


\section{I) Introduction}

UNOCA Mine Clearance Programme (MCP) now uses the figure of 10 million landmines in Afghanistan but that is an educated guess: no national survey has been done.

Further, officials estimate that it will take another two to five years to clear the known priority areas, but those are only a small percentage of the known dangerous areas. Whatever the actual figures, the dangers from landmines and unexploded bombs are well known to everyone.

\section{II) statement of Purpose}

The question is, how could an NGO such as the International Rescue Committee help out in mine clearance? This paper was commissioned by IRC's Rehabilitation Programme for Afghanistan (RPA) to:

\footnotetext{
-update IRC on what is happening in mine clearance

-explore ways that RPA could help, with new and existing resources, especially in agricultural lands in Paktia, Paktika, Ningahar and Logar provinces.

-explore IRC's strong interest also is work that could be community based

(parameters of study included as ANNEX 1)
}

PLEASE NOTE:

UNOCA uses the expression "mine clearance" as a catchall phrase referring to any work to do with landmines or unexploded ordinances. They divide this work into four areas:
1) mine awareness;
2) planning, surveying, mapping, marking;
3) manual or mechanical demining, and;
4 ) training.
This report uses "mine clearance" in the same all inclusive way. 
By late 1992, the Mine Clearance Programme (MCP) is in serious financial trouble. After being unable to pay deminers for two months, over half the teams (10 of 18) of ATC were released on unpaid leave at the beginning of october. Obviously, this has serious ramifications for demining progress and suggests the main way that any source could help: with funds.

The Mine Clearance Programme is negatively affected by lack of understanding in the public, mis-information and out of date information about it. And there has been further recent big changes that make it very much unlike its earlier days. These changes now make the MCP what may be the best co-ordinated of all sectors. Any assistance must go to complimenting this achievement, not diverge from it.

Experience has taught MCP people to be cautious and skeptical about "community-based" work related to landmines. They envision it to mean uncontrolled, unco-ordinated, unsafe, unsuitably trained amateurs who do not operate under the control, monitoring and reporting practised and enforced by the MCP. For very justifiable reasons of safety, and to compliment the strong co-ordination existing, any community level work would have to be up to these standards and in the system. However, this would require a whole new level of training and monitoring which doesn't exist now. There are problems with the expression, "community based" but it is mainly a matter of perception and semantics. Mine clearance now Is relatively community based.

While these details are pursued further, other ways of assisting are definitely possible; of most urgency is for NGOs and others to help find ways to keep the specialists in the leadership and at work. Additional ways are with information reporting and upgrading internal mine awareness training.

Interviewed for this paper;

-Lt. Col Mansfield, Programme Manager

-Andre Millorit, Director, Peshawar regional office

- Sayed Aqa, Director of Planning and MCPA

-Major Paddy Johnston, ATC technical advisor

-Abdul Kadir Khan, training officer, OMA

(Kafayattullah, Director of ATC and Fazel Karim, Director of OMA, were in Afghanistan and unavailable during the period of this study. Andre Millorit very kindly checked pages 12 to 27 for technical accuracy.) 


\section{IV) Mine clearance: The Biggest Issue}

By far the biggest issue and problem in the whole area to do with landmines -besides the inherent danger to everyone - is insufficient funding. This has a strong effect on how IRC might choose to get involved in the subject of mine clearance.

Each year, the amount received has fallen far below what UNOCA has asked for in pledges. By mid-1992, mine clearance is in a financial crunch. For three months (April-June) this year, just as the Kabul regime fell, and refugees started flooding home - the most critical time for mine awareness, the Mine Awareness Program completely ceased operations due to lack of funds. It has since been rescued with funding from the European Community (see "Funding" page 12).

As of september, deminers had not been paid their wages for two months and worse; as of October, over half of ATC's demining teams (10 of 18) have been sent on unpaid leave. A little money in the pipeline now may bring them back soon but the picture is unclear. Other basic problems exist, for instance important safety and communications equipment can not be acquired due to lack of funding.

Part of the problem is shortage of pledges and part is due to pledges made but not paid. A combination of these problems has caused the non-payment then lay-offs of deminers. (It was suggested tongue-in-cheek that a debt collection agency of actual deminers be formed to go out to the countries with friendly reminders to pay up. But in all seriousness, UNOCA MUST do something about public relations, fund raising and cash flow.)

For 1992, UNOCA had asked for pledges of $\$ 20$ million. But by september only $\$ 8 \mathrm{milli}$ ion had been pledged. In september, Colonel Mansfield, overall director of mine clearance said that another $\$ 4$ million would be needed just to keep everyone employed to the end of the year. At the time, he gave no indication that many would be laid-off almost immediately. Total costs of operation as they have been, run at about $\$ 1$ million per month.

For these reasons, options proposed to IRC are priorized according to basic needs not being filled now, not for anything new. When UNOCA can not cover it's own basic expenses, they obviously will not be funding anybody else to get involved. If IRC/RPA decides to pursue this subject, funding will have to come from outside. 


\section{V) Recommended options}

a) With New Resources

If it so chose and was able, how could IRC/RPA best help with new resources? The following list was made in "order of priority", by Colonel Mansfield. But the order of priority is not to be taken too strictly: all could be numbered as first priority.

Equipments

1. Ballistic Helmets: 350 units at $\$$ US $260=\$ 91,000$ These helmets, made in England, have been tested by the mine clearance programme and found to be virtually indestructible. They would save lives from shrapnel head injuries. Officials believe there would be not be problems getting deminers to wear them in the heat, etc. because they have seen enough fatal head injuries.

2. Communications Equipment. Codan High Frequency radios for ATC and SWADD. 24 units at $\$$ US $3,663=\$ 87,916$.

These radios are manufactured in Australia but are commonly in use in this part of the world. These radios are needed by demining teams to stay in contact with their offices and headquarters.

3. Mine Detectors: 30 units plus accessories, total cost $\$ 200,433$. Due to an internal reorganization, these additional detectors are needed. Made in Austria.

Operating Costs

4. Sponsor a Demining Team. $\$ 15,000$ per month including salaries and fuel. This is for an existing, already fully equipped (*) team whose other expenses for expendables are covered by the site office. Sponsoring a team would mean funding ATC (an Afghan NGO) to supply a team in RPA specified sites. This would work by officials adjusting the annual plan: first MCPA would go and survey the areas RPA specifies then the sponsored demining team would demine, under the usual direction and control by ATC and headquarters. (see pages 19 to 22 for more information). Note:* equipment for a team runs at about $\$ 350,000$.

5. Site office. $\$ 11,000$ per month. This office supports and coordinates two to three demining teams in the field. Above costs include accommodations, meals, fuel and salaries. (see page 19 for more information). 


\section{b) within Existing Resources}

If it so chose and was able, how could IRC/RPA best help with existing resources?

What are RPA's existing resources? These might be considered to be:

- community based human resources;

- funds and policies RPA and IRC already have;

- and ideas IRC could give others about the same.

\section{Human Resources: Community Based}

RPA employees a wide range of people who come in contact with thousands of others on a daily or occasional basis. The question is: could these employees be put to additional use for safety against landmines?

Specifically, we are talking about such RPA people and facilities as the shura manager trainees, liason officers, model farm workers, agricultural technicians and their farmer's groups, sites for seed multiplication, district grain stores, tree nursery workers, tractor trainees, animal vaccinators, project workers in irrigation repair, public health educators, sanitarians, EPI vaccinators, dental technicians, teacher trainees, etc. Could they help to make a community safer? How?

Could a sanitarian also play a role in mine awareness in communities where there are landmines? About a site manager on a kareez project: could he be given any responsibility about mines that might be there? What about agricultural technicians and their groups of farmers? Could they do anything? Teacher trainees hand out awareness materials?

First, please read the section of this report "Who is who and Who Does What, How?", pages 12 to 27. Collecting this information made me realize - and I hope it helps the reader understand - that the mine clearance programme is far more systemized, controlled, and dovetailed than is commonly thought. From my experience it is by far, the best co-ordinated of all sectors. This study has also made me realize that the answer to the above question - how to help with existing resources - is not as simple as we might have thought.

I have been re-taught how incredibly dangerous anything to do with landmines is: even professionally trained men with some years of experience and heavy monitoring for safety are being killed and injured. It is clear to me now that community based workers should not be involved unless they are fully trained and monitored in the existing system to do so. Making it more complex is that this kind of training and monitoring does not now exist, an additional or 
"para-professional" training would be needed. For example, for landmine awareness

- a relatively safe activity, there are now two kinds of training;

- a four hour session for the public (which is far too little to be of use for a community worker who is given responsibility in the subject) or a 10 day training session for potential teachers who are then monitored in EVERY class by a master trainer! How could a sanitarian, given that he already has one main duty, be trained? The 10 days training might be feasible, but it would seem necessary to customize it for his profession and specific location. But in any case, how would he be monitored?

Report? To do all this would take an expansion of the MCP or specially trained and monitored others of RPA. Is anybody ready for that?

And not that IRC has in any way suggested that there be community-based survey work or demining, but both surveyors and deminers are trained for four weeks then are under constant, expert supervision and on-going revision training. Even so, as stated, deaths and major injuries continue. This thought should continue to steer RPA away from any such work.

In addition, MCP officials have a negative view of what they perceive as "community based" work associated with mines. Please see "Independent Evaluation", page 10, which explains this attitude. They would not like to see such activity occur unless it was done as part of their official system already established for training, techniques, reporting, control, discipline, etc.

Asked about the hypothetical idea of say, a public health worker also playing some role in mine awareness, Col. Mansfield was hesitant although he did not reject the idea because it in itself is not a very dangerous activity (although the tight monitoring of teachers by master trainers, suggests that the possibility of wrong, therefore dangerous, information is high). And I DID have to continually reassure him and others that RPA was not proposing to turn its community based people into deminers. As a result of what was recommended in the external evaluation, "community based" is a sensitive subject with the MCP. But this seems to be mainly a matter of semantics.

Reading pages 12 to 27 , you should get a sense of mine clearance BEING relatively community based. First, it is entirely done by Afghans (foreign personnel remain in the background, virtually out of sight). Second, mine awareness teachers ARE village based. Third, surveying and demining is done according to choices and priorities of Shuras. Then dependence is put on the Shura for security, accommodations, etc. And Fourth, positively no other sector goes to the extent demining does to be accountable to the community. Upon completion, deminers risk their lives again to show their work has been done correctly. 
6 .

It must be emphasized that perception may the issue; not "community based", per se. To involve people at the village level, it would take mutual understanding and confidence building between the MCP and any NGO. It is only logical that the MCP leadership and tight co-ordination be respected and followed; nothing independent be done.

Col. Mansfield suggested an important alternative, "perhaps we need to be more sensitive to the needs of IRC/RPA and fill those better with ouR existing people". Although MCP's resources are now so constrained, this offer raises a most pertinent question: IS RPA effectively putting to use what services already exist from mine clearance?

In that theories of "community based" work are in question, I did not pursue specific ideas of it's practice and it is out of the realm of this study to clarify perceptions. Only general recommendations are feasible at this time.

\section{B) General Recommendations About Existing Resources}

1. Two things should be addressed simultaneously:

a) is RPA effectively using the existing Mine clearance Programme (MCP) resources? See priorities, ANNEX 2. The priority for surveying and demining are areas that are waiting with a funded project. But MCP officials must know about the sites and have them requested! close communications should be established between RPA and the MCP about RPA needs, district by district. What of these needs can the MPC fill?

b) What needs can the MPC not fill? Could these be supplemented by RPA workers? Would RPA be willing to have them do it under MPC's training, control, direction, reporting, monitoring, etc? Does MCP or RPA have the interest and resources to do it?

2. The subject at hand is a big one and warrants creating one position to follow-through from this report. He would liaise and co-ordinate with demining officials, first of all getting a very clear picture of what's already been achieved and what is planned in RPA project sites. He would also identify sites needing to be surveyed and demined and make the official requests. 
3. The future of mine clearance funding (like UN funds in general) might be so much in question that perhaps it's time for a new approach. Instead of mine clearance being thought of as a separate activity having only a special separate fund, maybe it's time to get everyone (UN agencies and NGOs) to look at demining as an integral part of their sectors and certain amounts of those budgets be allocated for clearance. For instance, large amounts are being put into restoring agriculture with seeds, fertilizer and irrigation but those are redundant in many areas unless mines are cleared. And it is unfortunate to avoid helping in places because of it being mined. Clearance should be considered the first rung on the agricultural ladder. In other words, agricultural budgets should include clearance budgets. The same could be said about other sectors; health, education, etc., as mines affect just about everything. There may also be instances where NGOs or UN agencies could afford to pay to have "their" land cleared, likely by temporary sponsorship of existing professional teams.

For IRC, the above would mean reviewing policies of it's cross-border programmes; both RPA and RAP (others?). Could you allocate any existing cash to mine clearance? What about the RAP? Since it funds Afghan NGOs for agricultural restoration, and mine clearance is carried out solely by Afghan NGOs, could RAP provide some funding to those NGOs?

IRC could use this study to bring others up-to-date and inspire them to consider moves they may also be able to make.

4. It's important to not get complacent that mine clearance is somebody else's responsibility and not forget that it is so basic. IRC and all NGOs in their home countries, should be lobbying governments to increase, start or at least maintain funding for it.

\section{Other Ways to Play Roles}

5. One possible very valuable role for all NGOs to play is reporting to the MCP, where landmines and bombs exist. A challenge in mine clearance is not knowing how much there is left to do. A national survey has not been possible yet (no funding to do so) and no province has been $100 \%$ surveyed, most only partially or not at all. "Missing" areas of need, need to be identified. MCPA attempted this in 1990 with a questionnaire to NGOs asking to have field workers fill them in when they saw mines in their travels or villagers complained about them. But there was a very poor response. They circulated 10,000 copies but only 8 or 9 were returned! RPA could make sure this is done by workers and IRC could 
influence other NGOs in the same areas and other provinces to do likewise. NOTE: this questionnaire is NOT in any way asking field workers to go looking for landmines (far too dangerous!). Reported information is to serve as an informal second reference for when villagers approach UNOCA for demining. And most importantly, it would help sketch-in remaining areas to be done professionally.

6. Refresher training: About existing Mine Clearance Programme resources...have all RPA workers had mine awareness training? Yes or no, OMA offers training that could be refreshed. Do you have any foreign workers who go into Afghanistan?

officials say an alarming the number of expatriates jump in a car and go inside Afghanistan with no formal mine awareness at all. IRC should insist, and encourage others, that such expatriates be trained. Invite mine clearance officials to your offices for group presentations.

7. Help locate missing minefield maps. When the Mujahideen took over communist posts, looting and destruction sometimes occurred. Officials believe that many of those posts had minefield maps. If not destroyed, these maps are now likely sitting unused in people's houses, as they are of no value to anyone except deminers. All workers in the field could be asked to keep their eyes open for them. The maps are very distinctive. Besides having a large hand-lettered title in Dari, "Landmine Map", they are colorful (mainly rust, blue and green) topographic maps.

C) Options Considered But Not Recommended

1. Research. Some of the officials were asked if they had questions or problems that could be addressed by carrying out any kind of study. None were identified.

2. Mapping: Officials were asked if electronic mapping was of interest-the "Global Postioning system" now being used by

DAI in agricultural mapping in Afghanistan. The answer consistently was that it would be a wonderful toy and probably very useful, but not on their list of priorities. The current manual mapping works well and is a kind of appropriate technology. The foreign military personnel involved in mine clearance are familiar with GPS. Andre Millorit, director of the Peshawar regional office is a mariner/yatchsman and has used the system in navigation and has been involved with companies who use it in deep sea exploration. 
VII) WHO'S WHO AND WHO DOES WHAT, HOW, WHERE?

UNOCA and each of the NGOs involved publish reports which are mainly data oriented. The following is included to give an overview of how each part works. See organizational chart.

a) "UNOCA/Operation Salaam", Organizational structure

First, to clear-up a little terminology...Higher than shown on the organizational chart is "UNOCA" or "Operation Salaam". About these two names, there is often confusion. What's the difference between the two? UNOCA representatives confirm that there is no difference. They are one and the same thing, with nothing occurring soley under one name or the other. "Operation Salaam" was coined by Prince Saddradin Aga Khan, when he was the UN General Secretary's representative to Afghanistan. He meant it to describe all the Afghanistan work that UN agencies do. "UNOCA" referred to the coordination of the UN agencies who do the work. But according to UNOCA insiders, Benan Sevan didn't like the expression so its use has become less and less common. The name is still around in print for the sake of continuity but you rarely hear it said nowadays. In other words, in regards to the subject at hand, it is correct to call it the UNOCA Mine Clearance Programme (MCP).

UNOCA was formed in 1988 and all functions related to mine clearance began in 1989. Mine clearance is now organized on three levels (not counting Geneva). Headquarters is in the UNOCA office in Islamabad. The overall "commanding officer" or program manager as he is called, is Australian, Lt. Col. Ian Mansfied, who reports to Martin Barber of UNOCA. Regionally there are three offices; Peshawar, Quetta and Kabul, respectively headed by a Britisher (retired military) and two Australians (active military personnel).

The third level is the work otherwise managed and implemented by four Afghan NGOs (MCPA, ATC, SWADD and OMA); a British NGO (HALO Trust) and Ronco, a private consulting firm which started the mine dog program (MDC). The work that each does is described in the following pages.

Altogether, about 2,000 Afghans are employed.

\section{Funding}

Funding from countries for mine clearance comes from countries to the Emergency Trust Fund for Afghanistan at UNOCA Geneva. From there it is allocated, according to availability, to the Islamabad headquarters, then to the various activities (awareness, surveying, demining, etc.) through their respective NGOs. 
10 .

Since the beginning of the program in 1989, funds or in-kind contributions for mine clearance have come from the following countries: Australia, Finland, Germany, Japan, Norway, Sweden, USA, USSR.

New pledgers in 1992 were Denmark, Netherlands, the United Kingdom and the European Community. IRC will want to take a closer look at what the European Community has begun in 92 . Whereas countries normally contribute to a general pot of money in UNOCA's name for mine clearance, the EC has chosen to get involved by directly funding an Afghan NGO which is taking a new direction. The NGO is the organization for Mine Awareness and the program is for work in Herat. The EC's funding is for mine awareness and for OMA to start demining, the first time such an agency has added demining to it's mandate. The EC funding is for $\$ 6$ to $\$ 7 \mathrm{million}$ for four projects to be carried out in 92/93. In this arrangement, all work will still be carried out completely under the normal un direction with the EC employing their own monitor. A proposal from ATC is also under consideration by the EC.

Budgets Landmine Clearance (in \$ million)

Asked for: Got: (reference)

$\begin{array}{lrrr}1989 / 90 & 54 & 17 & 1 . \\ 1991 & 18 & 12 & 2 . \\ 1992 & 21 & 8 & 3 .\end{array}$

1. UNOCA Third Consolidated Report, Oct. 1990, page 62

2. Operation Salaam Report for 1991, page 14

3. UNOCA Progress Repor:, Jan-June 1992, page 17

VII) c) Planning 
This function is carried out, in concert with all others involved, by the Afghan NGO:

Mine Clearance Planning Agency

address: UNOCA headquarters, Islamabad

Director: Sayed Aqa

In 1991, the external evaluation (see ANNEX 3) stated that mine clearance "requires a radical centralization of command and control". The way that the mine clearance organization, "constituted of multiple semi-autonomous organizations [meaning Afghan NGOs doing the different functions and presumably the headquarters] lacks the ability to coordinate efforts and utilize resources in an efficient manner."

Quite radical change does appear to have occurred. Earlier this year steps were taken so that planning, monitoring and reporting became more strongly centralized. Sayed Aqa, Director of the Mine Clearance PLANNING Agency (MCPA) who had been stationed in MCPA's Peshawar office, was relocated to the Islamabad headquarters to be at the centre of planning.

Now all regional offices and NGOs involved participate in joint planning. At the beginning of the year, a week-by-week, siteby-site plan was made from existing requests for surveying, mapping, awareness training and demining. A schedule was made for each of the teams of ATC, SWADD, OMA, etc. including time for training, rest and re-training (see "revisions" under role of foreign personnel).

Overall planning is up-dated monthly at "demining conferences" which rotate to different locations; Islamabad, Peshawar, Quetta. These are attended by the respective NGO and regional office heads. Here they hear the new requests from NGOs, UN agencies, and villages for demining specific areas. These requests are categorized according to established priorities (see ANNEX 2). and put into the plan if possible. See ANNEX 11 for the plan as it was before the recent layoffs of deminers.

But as can be imagined, priorization is often difficult because of the usual problems in establishing who the real local authority is, consequently what the real local priority is. Shuras may differ over what's most important, an NGO in the neighbourhood might have a different idea altogether. Planning therefore, often takes some delicate maneuvering.

Previously, requests for surveying and demining came to MCPA. Now, officially they are supposed to be directed to the regional office directors who feed them to the planning conferences. Every month there are on average 15-20 new requests for areas to be demined. 
At other monthly regional meetings, issues of regional concern are discussed. Some of this content also results in plan changes.

The external evaluation was in many ways, very tough on the mine clearance programme, more or less stating that there was no co-ordination at all; that everybody involved was off doing their own thing, competing instead of co-operating. visiting headquarters, and talking with officials, there seems to be little sign of this now.

Amongst officials, there is consensus that big improvement has occurred this year. Some attribute it to useful recommendations made in the external evaluation. Others reject the evaluation. Sayed Aqa attributes the positive change more to the program simply being in its fourth year of practice, everyone learning from their mistakes and figuring out new things and refining others. He's been with the programme since "day one" so has this time perspective.

Headquarters does have the atmosphere of it being in command or being a "nerve centre". Lt. Col. Mansfield, commanding officer, and sayed Aqa, director of planning, have side-by-side offices. The largest of the four rooms is the information centre: it's for the map collection, data collection and computer input from reports as they come in from the field. One large shelving unit holds the detailed paper records of all field work in progress, completed and planned for mine awareness, surveying, mapping and marking, manual and mechanical demining. At the centre of the rooms is a wireless radio which seems to always be in use, in contact with teams in the field.

From this location Sayed Aqa plays a dual role; the director of planning and director of his own NGO's (MCPA), Peshawar-based operations for surveying and mapping. Taped to the wall close beside his desk is the plan for the last four months of 1992 (ANNEX 11). At a glance he can see where all 2,000 mine clearance workers are, and from radio contact have an idea of progress. From what the evaluation suggested, it wasn't like this before.

(IRC/RPA may be interested to know that sayed Aqa was employed by RPA in early 1988 in charge of agricultural land survey). 
vII) d) Surveying, Mapping, Marking

Officials point out that mine clearance operations begin and end with the shura (see "Demining" for the remarkable way in which it ends).

According to the annual plan, an MCPA survey team of 4 men with a driver goes to the designated site. Here they meet first with the shura to ask for assistance; provide accommodation, security, information about known mines, who of the village knows most about the mines, etc. and for assistance to be provided for the teams of deminers who will arrive later (60 to 100 people).

The Shura is asked to decide the priorities - which places are the most important to be demined. As can be inagined, this is not an easy job because every shura would like all their placés surveyed and demined. In comes another skill. Sayed Aqa said, some "team members are now really skilled in negotiation" and they put this to use, getting Shuras to narrow down and prioritize their choices. All the local sites will be surveyed then, but only the priority areas will be demined in the near future.

According to these choices, the survey team sets about to roughly locate the mines or random explosives. Local people's knowledge is used as well as detailed observation. As the location of known or suspected explosives are identified, the perimeter of the dangerous area becomes more clear. Marking and mapping then begins.

Two different kinds of marking are used; temporary and permanent. Temporary is used if the site is to be demined within six months (the highest priority, as chosen by the shura). This kind of marking consists of red-painted rocks placed all the way around what is determined as the boundary line. Permanent marking is used to identify the perimeter of dangerous areas that are of lower priority and will not be demined until sometime after six months. The permanent markings consist of three cubic metre gibbons filled with stone. These are dug-in one and a half metres below ground and show the same amount above ground. They are placed only at the "turning points", where angles in the boundary change. The idea is that all these markers should be visible from a distance, warning people that inside these markers is a minefield. (The mine awareness program teaches people what lines of red rocks and groups of gibbons mean).

In the past, minefields used to be marked with a bamboo pole holding a red flag but people took them. So thought was put into using something people wouldn't take. What is it that Afghans don't need? mine clearance people asked themselves. Rocks was the answer. Although there have been some problems with paint washing off the rocks, there are no reports of stolen rocks. 
Mapping is done on site, at the field office. (See samples: ANNEX) 6). Using compasses and the US Corp. of Engineers 1:100,000 (19689) topographic maps, the site's general and specific location is identified. From here, a series of maps are hand made, to scale with legends. These are to be used later by the deminers to locate and plan their work.

The first to be made is the "Area Map for General Location", which is traced from the above 1:100,000 map. In the samples you will see this (fourth generation photocopy) map for Herat. MCPA number codes the general location map to correspond with the numbering system of the 1:100,000 maps. See at the top of the sample it says, "sheet 1485", meaning sheet \#1485 of the original topographic map. Quadrants (in this case, 05/75 and 97/40) are also included so that others can line up this map on the original to check for precision. In the hand drafted general location map, you will see dots inside rectangles, each with a number. These numbers indicate the number of maps that follow in the series, showing in detail each minefield. Out of the series of nine made for Herat minefields, three are included here as samples $(001,002,003)$.

To locate and map the minefield, bench marks (BM), reference points (RP) and starting points (SP): all prominent landmarks are first identified and marked with paint. If you passed through a village and saw a boulder or house wall with a huge red "sp" or "BM" painted on it, this is a sign that a mine survey and mapping has been carried out. Further observation on the ground and in the maps show where the outline is drawn and marked with "turning points"-where the angle of the outline changes.

It should be mentioned that all areas where there are mines or unexploded ordinances are referred to as minefields whether the explosives are systematically or randomly placed. In each case, the area is marked and mapped the same way, the outline being many sided. You will note in the map sample, that the outline is made up of several joined straight lines, the significance of which is explained in "Demining".

About each site, several kinds of information is collected: what kinds of mines or unexploded ordinances are present, who laid them and when. A "photologue" is produced; that is a series of photos of the site, that when put side-by-side show the 180 degree panorama. On the photo is coded the dangerous and safe areas, reference points etc. This serves as an extra reference to the maps produced. Photos are taken of the main village people who are most knowledgeable about the mines and provided information. The maps and all the other information are put together as a written report on the site.

When all the information has been collected and the perimeter of the dangerous area precisely ascertained and marked, the survey members sweep with a mine detector along the boundary line, one 
15.

meter on each side. This is to make a clear path around the minefield for the deminers when they arrive.

Next, the demining team commander whose team will do the clearing comes to the site for a briefing by the survey team leader. He is shown all that was found and given all the above detailed information to prepare him and his men for the job to be done.

For an average minefield of $50,000 \mathrm{sq}$. metres, it takes about one week to survey, map and mark it. The quantity of surveying completed stays about six months ahead of demining completed.

Each survey mission lasts 45 days to 2 months. Each team hás an assignment on what to try to complete within that time, staying in daily radio contact with the Islamabad office. As one task is completed they move to the next site. After each mission is completed, they come back to Pakistan for rest, repairing equipment, getting fresh supplies, etc. but, like with demining teams, there are always survey teams in the field on rotation, spelling each other off.

It's worthwhile stating, that surveying and mapping is known to be as stressful and dangerous as the actual demining. At least when deminers arrive on site, they have a good idea of the general location because surveyors have already been there. Several of the people killed, and many of those injured, have been surveyors. 
IV) e) Demining and How It's Organized

Demining is carried out by two Afghan NGOs; SWADD and ATC and one British NGO: HALO Trust

-SWAAD (South West Afghanistan Agency for Demining (Quetta), works in the provinces of Khandahar, Helmand, Badghis and Zabul. They have 10, 32 man teams.

-HALO (Hazardous Areas Life-support organization) Trust has their base at Pul-i-Khumri, Baghlan, and works in Baghlan, Parwan, Samangan and Balkh. They have 2, 32 man teams.

-ATC (Afghan Technical Consultants)

Director: Kafayattullah

Address: 45-D Old Jamrud Road, University Town, Peshawar

Telephone: 812921

-ATC is by far the largest of the demining agencies with 18,32 man teams. ATC works in IRC/RPA provinces of Paktia, Paktika, Ningrahar, Logar and several other provinces.

\section{i) site offices}

ATC maintains seven site offices in Afghanistan. These move around to different locations every three to four months, to more or less stay at the centre of demining teams. Ideally they are no more than 30 minutes away by car to the teams. Here the deminers, mine dogs and their handlers live for the period of assignment. other site office functions are to co-ordinate with the shura and other local people, supervise the demining operations and report back to headquarters.

The site office is staffed by a site supervisor who is the overall commanding officer of the area's demining, an operations officer, an administrator, logistics officer and various other support personnel; guards, storemen, cooks, etc.

Another important element of the site office is the medical unit, staffed by one doctor and a few nurses. The doctor stays at the unit, while one nurse, prepared for first aid in emergencies, goes each day with each team. An ambulance with a radio or another designated vehicle stands by. This unit also offers medical aid to the local population.

From each site office, two to four teams (64 to 128 people) stay and it is from here that they operated. The number depends mainly on the demand for demining. 
Site offices, like demining teams, shift locations according to schedule and time of year. There are winter and summer programmes. In summer, deminers work where it is impossible to demine in winter. In winter they move back to warmer areas.

IV)e) ii) The Demining Team

A demining team consists of 32 persons; a team commander, an assistant team commander, three section commanders and nine "breaching teams" which are comprised of three deminers each.

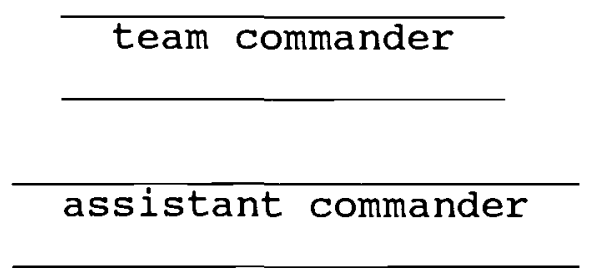

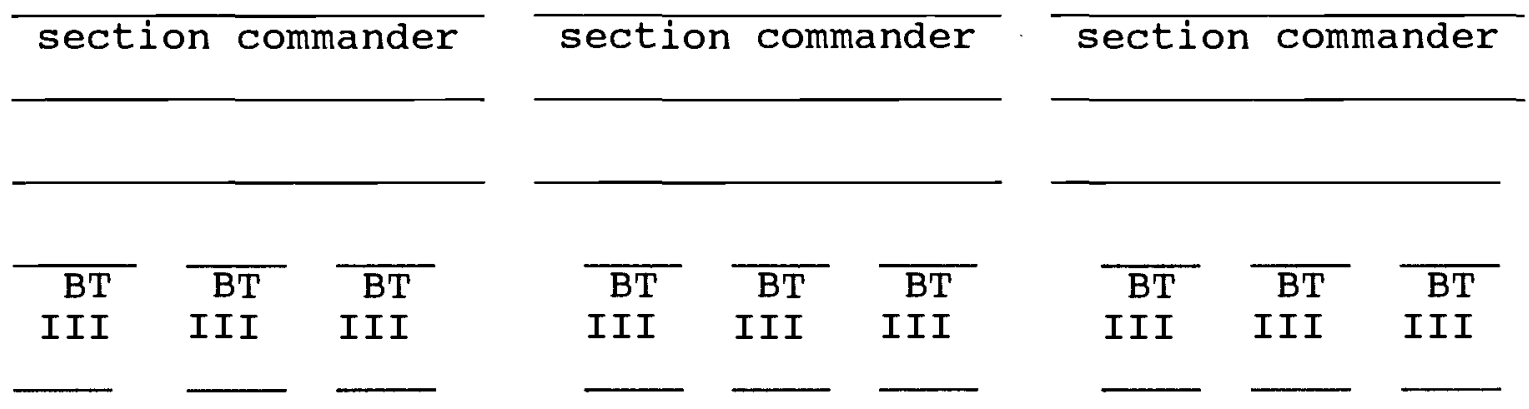

BT: breaching teams comprised of three men each

\section{IV)e) iii) How Demining is Done}

From the briefing and materials provided by MCPA, the site operations officer divides the minefield into sections and makes a general plan on how to tackle it. How to tackle each section is then planned by each team commander assigned. Once this specific plan is approved by the operations officer, the team starts to work.

As you'll see in the sample maps, each minefield has many straight sides. The first step in planning is to decide from which side demining will begin. From the chosen side, the minefield is divided into imaginary (unmarked) two metre wide strips that are at right angles to the starting line. Into these "lanes" go the 
"breaching teams" (actual deminers) who work down to the full length then back on the next lane until the section is completed.

As the breaching teams work, they must stay 50 metres (several lanes) away from each other for safety sake. Part of the section manager's job is to watch that the $50 \mathrm{~m}$. distance is observed. They also keep the teams going in the right direction and inside their lanes.

At the end of each day, the section commander tallies up and enters in a journal how many metres of land has been covered by each breaching team. Each night this is reported to the operations manager who shades in the amounts on their MCPA map, helping to clarify how the plan is progressing. At the end, this fully colored map forms an important part of his completion report.

IV)e) iv) "Breaching Teams"

These are the actual deminers who work together in groups of three men. Whenever you see a photo of deminers at work, you will often see one man working on the actual explosive and two others standing, looking rather aimless, in the background. This is not ignoring rules of good photography composition, those other two are standing by to take their turns.

Each man works in 20 minute shifts. A man walks down the two metre wide lane, slowly sweeping a detector over every square inch, listening for signals on earphones. When the detector signals that something is in the ground, he marks the spot and hands the job to the next man waiting and goes to the back of the line. This second man's job is to start gently probing the ground to locate the thing detected. To do this, all deminers now use a kaleshnakov bayonet. over the years of the demining program various tools have been tried but the bayonet has proved to work best in the hard ground. The prodder man also works for 20 minutes with the third man replacing him after twenty minutes and so on until some part of the thing underground has been exposed. The men rotate in the same shifts, whether anything is detected or not.

They take short shifts like this because the job is so stressful. In some places there is constant noise in the earphones. This noise, extreme heat or cold, their training to be constantly alert and memories of deaths and injuries on the job, makes for a tense 20 minutes.

Detonation of mines found is carried out by the breaching team.

A surprise in this high-tech day in age is that nothing more sophisticated is available to manually detect mines. Those detectors in use are the best available, and are NATO approved for demining, but they don't specifically detect mines, they detect everything metallic in the ground: a button, a can, or a spent 
rifle shell. And the trouble is, in most places there is a shocking amount of metal garbage. Mine clearance records (see ANNEX 7) show that there's often 100 times more metal garbage found (what they call "fragments") than explosives. For example, in August of this year, ATC found 321,763 fragments and 3,074 anti-tank (AT), antipersonnel (AP) and unexploded ordinances (UXOs).

Obviously, a great deal of time is spent locating and digging up things that are not dangerous. This is what appears to make demining such a slow process. Officials seem surprisingly calm and accepting of this: but they know they have no choice about the technology. When demining must be done in such terrain, it must be manual. And the world's top military knowledge says that nothing manual has been invented yet that can distinguish between a piece of metal and an explosive. There's no new technology is on the horizon either. This is why mine dogs are becoming attractive.

At the same time, practice and new methods have resulted in deminers being able to work more quickly than earlier. For one thing, deminers have developed their own uncanny sense of what the detector is telling them; kind of understanding its language. A certain kind of sound means a certain kind of thing could be underground and they take action accordingly. Another time saving technique is to no longer expose the whole mine. Only a little bit needs to be uncovered to blow it up.

An additional change being introduced now, which will help in covering more ground quicker, is two-man breaching teams. As an experiment, the third position is being done away with and additional breaching teams formed of these men. This change is proving effective but is still under trial.

\section{*}

As stated earlier, mine clearance begins and ends with the Shura. When a minefield is determined to be completely cleared, the shura and all other local influential are invited to the minefield. The grand finale of demining is to have these leaders watch as deminers walk or drive over the minefield! This is to show the people that the deminers are confident about their work and to instill confidence in the people about using the land again. ATC says that they have had a $100 \%$ success rate. There has never been an accident at this time nor have any been reported on land they've cleared, "and believe me, if there'd been accidents, we'd hear about it", said Major Paddy Johnson, an ATC adviser.

Once a minefield has been cleared, there are no visible signs for a stranger passing by to know that demining has occurred. only from official records and from villagers can you know that it has happened. As the field is cleared, deminers are supposed to get rid of the red rocks. Occasionally this hasn't happened and some confusion has been caused. 
Mines in Afghanistan have outer shells of either plastic, metal or wood. The plastic covered mines are the hardest to find but all mines having varying amounts of metal in them. These variations are what makes detection so tricky. This is where mine dogs have become so useful. Dogs' sense of smell is thousands of times greater than humans'. Mine clearance now has 50 dogs trained in identifying explosives, no matter what other materials are present. This also means that mine dogs don't waste any time detecting metal "garbage". All they smell is the explosive. And, inexplicably they "alert to" (detect) trip wires. They are especially used on roads, as this is where the plastic mines are commonly found and they are more effective on hard compacted earth than the detectors.

The dogs are trained "to alert", that is, when they get the scent of an explosive, they are trained just to sit down and wait. one particular dog has made himself everyone's favorite by additionally howling and barking. He wasn't trained to do this, it's his own idea.

Dogs however, have their limits. Because their sense of smell is so sensitive, they can't work where it's wet or if other strong smells exist. For example: where very heavy over-growth has occurred of a minefield, it is first necessary to burn off the brush. In this case, the scent of the burnt landcover overrides the landmine scent. And after a mine has been blown-up, the scent that remains in the air, makes it impossible for dogs to smell a finer scent.

The popularity of using dogs has grown enormously in the past year or two. Their Afghan handlers and deminers have gained a great amount of respect, affection and trust in them. But they won't ever replace the other techniques.

At the present time the dogs are trained under the supervision of Ronco, an American consulting firm. This year, this programme is being absorbed by UNOCA and some dogs are being shifted from demining to survey teams, where they have proven to be most useful.

\section{IV)e)vi) Mechanical Demining}

The flails now are under ATC authority and operation. About the flails, authorities say that they are "very effective" when they are working properly but trouble continues. At the end of September, both are out of commission. One is parked at Hyatabad with it's engine blown. The other is broke down in Jalabad. Flails are state-of-the-art, expensive to operate and apparently sometimes put to work in conditions for which they were not designed. Underfunding, inappropriate use and non-use (especially when they

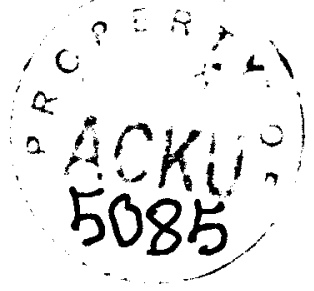


became a popular target of the former Kabul regime and had to be withdrawn), has contributed to the questionable image they have, fairly or unfairly. One big advantage of the flail is that does all operations in one; locating and blowing-up the mines and is, by far, the safest way to do it. Where these machines are in use around the world, there never has been a casualty.

In the beginning, foreign consultants were present to do all the repairs and maintenance. Now Afghans do the repairs and maintenance with spare parts being available only from the manufacturer in scotland.

\section{VI)e)vii) New Machines Being Looked At}

A possible improvement over the flails is a special demining bulldozer developed by the Caterpillar company; already in use, its literature says, in "south east Asia" (Cambodia?). Full color promotional material is making the rounds between all mine clearance people and for now, this may just be for entertainment purposes. There's no money to buy any anyway. The idea is attractive though, because spare parts would be much more easily obtainable - Caterpillar being just about everywhere. It is a standard D7 bulldozer, but fitted with armour plating, has an enclosed cab and has what they call a "rake" or kind of sieve for a blade. It's versatility is another attraction. Replace the rake with a blade and it's a regular bulldozer (except it's painted that menacing, stealth-like black-green).

This machine however, does not dispose of the mines, only rakes them to one side where they still have to be dealt with by hand.

\section{IV) f) Training}

In the beginning all deminers were trained at a centre established for the purpose at Risalpur, located north of the Grand Trunk road towards Mardan. But it now is hardly used (about once every three months) because now almost all deminer training happens in Afghanistan. 


\section{IV)g) Mine Awareness:}

The only source of mine awareness training is the Afghan NGO: organization for Mine Awareness (OMA)

$D-3 / 21$, street 9

2nd Ghazali Road, Phase I, Hayatabad

Director: Fazil Karim Fazel

-OMA is working with 11, three to four man teams in Paktia, Ningrahar, Logar, Helmand, Kandahar, Laghman, Badakshan, Kapissa and Herat.

As of 1992, mine awareness training occurs in Afghanistan only. For the first two years (89-90) the program was completely in the camps. At the end of 1990, it started inside Afghanistan. During 1991, the program continued in the camps but also expanded inside Afghanistan. At the beginning of 92 , it was totally shifted inside, with the camp program closed.

OMA's goal is to reach $25 \%$ of the population. The idea is that if one in four have their awareness raised, they are likely to transfer that awareness to friends and family. Since July '89, 840,000 Afghans have attended the awareness course.

To select sites to give mine awareness training, OMA first does a general survey of a province or district to get an idea where mine awareness is needed most. Local authorities are involved in choosing and priorizing the places. These sites are then put into the plan.

According to this plan an OMA team, consisting of a superviser and two to three master trainers, then goes to the specific sites to meet with the Shura and other locals to explain OMA's aims and objectives. They ask the Shura to identify who should be trained as "potential teachers". Those nominated are given a written exam and needed teachers are hired from those who pass. These teachers are then given 10 days training. ( $I$ could not get it clear why these trainees are called "potential" teachers as only those hired are trained and all work as ACTUAL teachers. It was explained that this expression started while IRC was in charge of the mine awareness program and the name has stuck).

These teachers are employed by OMA for the duration of the program in the area. When the target number has been reached, the program ends.

At each site, the teacher is responsible to recruit people who will attend the training session. He signs up a maximum of 20 people per class, scheduling more classes according to demand and time allotted in the site. 
Each session is now four hours. Originally it was six hours but it was cut back because it's too hard to maintain trainee attention for that long. The class is given in two parts; 2.5 hours of theoretical and 1.5 hours of practical.

The theoretical part is a lecture of five lessons. Covered are the basics about what different mines look like, where they are commonly placed, the distance of safety, the dangers, etc. Each lesson ends with questions to the students to check to see if they have understood the information.

For the practical part, the teacher sets-up an artificial minefield, using mine models. They have students walk in this area, showing such things as how to get back out of a real minefield should they find themselves in one.

In every class, an OMA master trainer is in attendance. He remains quiet but is present to correct the teacher if necessary and answer questions he can't. The master trainer does not teach because he is unknown to the people, whereas the teacher is a local known to everyone. It is a matter of the local being more trusted and understood and to leave behind a very well informed person who could play a role in further awareness.

The majority of students are children between the ages of seven and fifteen. OMA says this is because parents are busy and that's okay because they already have some awareness and information. It's the children who need it most.

At the end of the class, trainees are given materials to take home: a mine identification booklet, silkscreen posters, etc. Especially from these take-home materials OMA counts on the multiplier effect for awareness.

Another role of the master trainer is to make sure the materials are distributed and data sheets are done on each student. These involve the usual questions to positively identify someone, where they live, date and place of course and if the student has ever seen some landmines. Each master trainer is responsible to monitor 2-4 classes a day, depending on the number happening.

This year, when the government fell, a new approach was introduced at border crossings. Here some effort has been made to warn people of the dangers. Display cases of mine models (made by IRC in Hangu) were installed in prominent places and OMA workers are present to hand-out materials and talk to returning families. 
While the program was happening in the camps, females were also given mine awareness but since the program moved to Afghanistan generally this has not been possible. A team of female master trainers has been kept to start again in Kabul and Jalalabad when it is safe to do so. In Herat now, a team of female master trainers Is running this program for women.

\section{Where It Is Completed}

OMA considers mine awareness finished in four provinces; Paktia, Paktika, Kunar and Helmand. In these provinces the target number $-25 \%$ of the population - has attended the sessions.

\section{IV) Role of Foreign Military Personnel}

In earlier days, there were a high number of foreign personnel involved but now there are only 16. 12 of these are an Australian contingent that make up the Mine clearance Training Team (MCTT) and includes col. Mansfield as the chief technical advisor and commanding officer. Two of the other Australians and a Norweign work directly with the heads of MCPA, ATC, and SWADD and as managment and technical advisors. All of the salaries of these Australians are paid by the government of Australia as they are employees of that government and they receive UNOCA'S DSA. The government of Norway funds the position for the one Norweign. Regional office heads, two other Australians (quetta and Kabul) and a Britisher (Peshawar), are paid from UNOCA funds.

The role of the majority of these personnel is training, monitoring and revisions. The MCTT trains new deminers; trainers of surveyors and deminers and team commanders. Twice a year MCTT aims to monitor each demining team mostly for safety factors. If needed, they then provide revision training. Another main responsibility of the MCTT is to investigate all accidents, whether causing death or injuries from mines or even serious trafffic accidents. But none of the Australian personnel do any kind of actual demining.

It is highly unlikely that numbers of foreign personnel will ever increase from the current level. Attempts have been made to interest contingents from other countries but unsucessfully. 


\author{
EVALUATION OF THE MINE CLEARANCE \\ PROGRAMME IN AFGHANISTAN \\ (PUBLISHED - JULY 1991)
}

RESPONSE AND REVIET OF IMPLEMENTATION BY UNOCA

(A8 AT 1 MARCH 1992)

The text of the recommendations contained in the Executive Summary of the Evaluation Report is reproduced below, along with the response of UNOCA and an update on implementation.

\title{
SECTION 1: THE RATIONALE
}

Recommendation 1.1.

A shift in rationale should be incorporated into' the design of the demining programme. Although slight, and although the programme has made strides in this direction, this shift entails significant consequences. An emphas is on village level rehabilitation and economic development should replace the previous emphasis on refugee repatriation. Meeting the demands of this new rationale will require considerable changes in structure and operation that are discussed in later sections of this report.

Response 1.1.

New criteria for the selection of the sites for demining have been approved (Annex 1). Sites are being selected in consultation with other agencies of the United Nations system and NGOs.

\section{SECTION 2: THE INSTITUTIONAL SETTING}

\section{Recommendation 2.1}

The demining programe needs an institutional mechanism for more direct interaction with donors. It also needs a more stable funding environment in order to facilitate long term planning. Since UNOCA does not appear able to provide such an environment, an effort must be made to find a new institutional home for the demining programme. 
Response 2.1.

An ad hoc group has been set up in Islamabad bringing together local representatives of donor governments with UNOCA for regular reviews of the programme.

However, it is widely felt that the United Nations system needs to have a coordinated approach to mine clearance as part of its humanitarian relief and rehabilitation programmes. This need will be brought to the attention of the new Emergency Relief Coordinator.

In the absence of agreement on this matter, it has been decided that the Mine clearance Programme in Afghanistan should continue to be executed by UNOCA in 1992 .

\section{Recommendation 2.2}

Locating an institutional home'needs to consider two crucial factors: (1) The demining programme must continue to work under the umbrella of neutrality that the United Nations is able to provide. (2) It must have the freedom to operate independently of the Afghan government. The UNDP seems a logical choice. Its advantage is that UNDP is able to offer the demining programme this umbrella of UN neutrality. Its disadvantage is that through its Resident Representative, the UNDP is inevitably affiliated with a host government. For this reason, it is recommended that the demining programme be administered by the UNDP but in a section especially designated for demining operations, under an understanding that such a special section has the freedom to operate with strict political neutrality, i.e. with no obligation of allegiance to the Afghan government.

Response 2.2.

This recommendation has not been agreed to.

SECTION 3: COORDINATION, COMMAND AND CONTROL

Recommendation 3.1 .

Demining programme headquarters should be moved to a location more centrally placed and should, ideally, be detached from UNOCA. This central, headquarters should incorporate the functions of programme management, technical planning, logistics, and most particularly managing reconnaissance, analysis of information, planning operations, setting priorities, monitoring and evaluating 
the efficiency of operations.

Response 3.1.

It has been decided that the most appropriate location for the Mine clearance Programme Headquarters is at present Islamabad. As soon as it is possible to move to Kabul this will be done. Action has been taken to incorporate all the functions 1 isted in the recommendation into the Programme Headquarters.

Recommendation 3.2 .

The Mine Clearance Planning Agency need no longer exist as a separate entity. Survey teams should be deployed with the logistical support of the demining agencies. The information gathering, planning and monitoring functions should be subsumed under demining headquarters.

Response 3.2.

The recommendation has been implemented, with effect from January 1992.

Recommendation 3.3

The Organisation for Mine Awareness should continue with its independent programme of mine awareness training, exclusively in Afghanistan, for a limited period of time. This independent phase of the programme :

should expect to terminate within 18 months. Following this, OMA mine awareness training expertise should be

deployed by the planning cell at demining headquarters to design and administer particular training programmes tailored to the needs of individual villages or groups of villages. This training programme should provide a

village strategy for avoiding mines and fencing mined areas. This village-level programme of mine awareness should incorporate the patterns of movement of women and children in grazing, fuel and water gathering activities in an attempt to establish alternative routes or alternative means of satisfying basic needs.

Response 3.3 .

The OMA Mine Awareness Programme will operate only in Afghanistan in 1992. The longer-term response to this recommendation will be reviewed in 1992 .

Recommendation 3.4 . 
There are presently steering committees at nearly every-level of operations. In place of these separate steering Committees, one steering committee should be established to guide and advise the activities of demining headquarters. Every political and power group must be represented on this one steering committee and its members should be appointed by the programme manager.

Response 3.4 .

The new central steering Committee will hold its first full meeting in March 1992.

Recommendation 3.5 .

The planning cell at demining headquarters should coordinate the activities of all mine clearance and education services in their design and administration for each village or set of villages.

Response 3.5 .

Recommendation being implemented.

Recommendation 3.6

Demining headquarters should seek to incorporate innovative approaches to village-level demining. Some of these are discussed in the following section. One possible approach would be to assign two instructors with

team leader experience to a single village to train a demining team among village members which will then clear mines from village areas. Demining headquarters would, in this case, supply only the required equipment and the salaries of the two instructors.

Response 3.6 .

This recommendation has been carefully considered and discussed with all concerned. However, it has been decided that it cannot be implemented at present. Mine clearance requires consistent training, retraining, monitoring and control over equipment. This could not be guaranteed if this recommendation was implemented.

Recommendation 3.7 .

Plans for demining operations should be discussed with other development organizations prior to implementation. Every attempt should be made to coordinate demining activities with an overall assessment of village needs. once canals or karezes are cleared of mines, a canal 
clearing project might be undertaken. Once fields are cleared that have been out of cultivation for some years, herbicides may be provided to tackle the weed problems.

\section{Response 3.7 .} Managers.

This will be the task of the new Assistant Programme

Recommendation 3.8 .

The evaluation strongly supports the present move to close Baleli camp. It also recommends the closing of Risalpur training camp as soon as is feasible. Training programmes should be administered on site, in Afghanistan, where students can receive hands-on experience in mine fields. This may mean a considerable reduction in the number of expatriate expertise required.

Response 3.8 .

Baleli camp closed on 1 September 1991. Risalpur camp will be retained during 1992 however the emphasis will be on conducting training in Afghanistan. of the seven courses run so far in 1992, five have been in Afghanistan. It is envisaged that international military personnel will be required for a few more years to ensure that standards are maintained and to provide independent analysis and evaluation.

Recommendation 3.9 .

The demining agencies should seek to make their field sites as mobile as possible. Since communication and transport is so difficult, field sites should be placed as close as possible to task areas. This means the creation of more sites with fewer teams per site.

Response 3.9 .

Most site offices consist of tented accommodation, and are generally not more than 30 minutes travel from mine clearing sites.

Recommendation 3.10 .

The demining operation must undertake to incorporate Kabul based activities fully. The existing demining expert should be replaced with someone who is capable of accepting 
and carrying out a much wider mandate of responsibilities. This person should work closely with Halo Trust and create a much closer working relationship between Halo Trust and demining headquarters than exists at present. The selection of sites and the monitoring of operations by Halo Trust should be submitted to the same rigorous review as the activities of other demining agencies. Even more importantly, however, the demining representative should spearhead a shift of demining headquarters to Afghanistan. (See section 6) This is a complex task which will require considerable management and diplomatic skills. A plan for this shift should be developed within the next six months.

Response 3.10

The post of an Assistant Programme Manager has been established at the L4 level, and an ex military officer will assume duty in Kabul on 1 March 1992. The contingency plan for shifting Headquarters to Kabul will be developed by 30 April 1992 .

\section{SECTION 4: RECONNAISSANCE AND PLANNING}

Recommendation 4.1 .

A planning cell should : established with ,..... ing headquarters which $w i$ over all responsib or supervising the cil: ... f information, planil... ... the basis of this inf : n....ion, keeping records and monitoring programme performance.

Response 4.1.

The planning section of MCPA has moved to Demining HQ in Islamabad in January 1992.

Recommendation 4.2 .

This planning cell would perform many of the functions now performed by MCPA. It is envisioned that the survey teams would report directly to the planning cell. It is also envisioned that the planning cell should design and schedule the tasks for which demining agency teams are deployed. MCPA should therefore be discontinued as a separate institution. The resources presently at its disposal should be placed at the disposal of the planning cell within demining headquarters. 
Response 4.2.

MCPA has continued as a separate NGO for practical administrative reasons, but its functions have been re-distributed as recommended.

Recommendation 4.3 .

A key function of the planning cell should be to devise a mix of mine eradication and education services to a given village or cluster of villages. This mix of services will differ in each case. On the basis of each individual plan, the planning cell will deploy the appropriate selection of mine clearing operations, education and mine avoidance operations, as well as the deployment of innovative techniques in mine eradication such as operationalizing Village Demining Teams.

Response 4.3.

This concept will be developed during 1992, with a programme of work issued by March 1992 .

Recommendation 4.4.

A pilot project should be initiated to form and deploy Village Demining Teams. These are teams formed by villagers from local villages who, under the guidance of two trained Afghan instructors and one expatriate, are trained and then employed in demining activities in their own area. If the pilot project is successful, then a plan for applying this approach on a wide scale should be developed.

Response 4.4 .

This recommendation has not been agreed to. (See also 3.6 above).

Recommendation 4.5 .

Completion report formats should be revised to provide considerably more detailed information.

Response 4.5 .

This has been reflected in the standard operating Procedures and standard Reporting Procedures. To accomplish this and many of the following recommendations the NGOs must have good communications, trained staff and computers. This requires adequate funding which has not yet been available. Reporting procedures were issued in 
Response 6.1.

A Memorandum of Understanding was signed in February 1992, which gives UNOCA Demining Programme responsibility for the deployment of the Mine Detection Dogs and provides for phased hand-over of total responsibility for the Programme over an 18-month period.

Recomendation 6.2 .

The Flail operation should cease immediately once the Urgun task is finalised. Replace clearway team with a specialist national group from a donor country such as

Sweden/Norway. Both have had extensive experience in flail operations in Lebanon. The flails should not be phased out of service. They should be returned to Peshawar, overhauled and serviced then held for a period of at least 12 months whilst further Afghan training and more effective future planning can take place. Both a technical and planning review should start immediately using the services of the NZ Warrant officer who is a qualified plant supervisor.

Response 6.2 .

The review of the operation of the Flails is complete. The contract with clearway was not renewed. The flails were overhauled in Peshawar in late 1991, and currently limited flail operations are taking place in Khost with only limited expatriate support. Their progress will be closely monitored.

\section{SECTION 7: POSTSCRIPT: INTO AFGHANISTAN}

Recommendation 7.I.

A'comprehensive plan for shifting the administration of the demining programme to Afghanistan should begin immediately. It should be prepared by the demining expert resident in Kabul. The final should be submitted within six months.

Response 7.1

The plan for the transfer of the administration of the Demining Programme to Kabul is being drawn up and should be completed by 30 April 1992. The plan will be implemented when other United Nations agencies move their Headquarters to Kabul. This is likely to be as soon as an Interim Government is established. 
Priority for the selection of locations for demining operations during 1992 will be given according to the following criteria:

1 The area has been secure for several months

2 The population living in the area will derive immediate economic and/or social benefits from the demining

3 The local representatives of all parties and groups are united in requesting assistance with demining

1. The local population is willing to contribute something to the exercise (eg. accommodation, food, support staff for the operation etc.)

5 The local population has been suffering from the presence of the mines

6 Access roads of strategic importance will not be taken as demining tasks. 


\section{COAUENTS ON THE EVALUATION REPORT OF THE MINE CLEPRANCE PROGFARThE IN AFGHANISTPAN}

\section{INTRODUCTION}

Dur comments on the evaluation report are not based on sentence by sentence of the report. They based on the critics of MCPA activities in particular on the matters in directly eftect MCFA operations in general.

\section{COUENS:}

a. UNOCA has been set to coordinate the humanitarian and ecomomic assistance to Afghanistan. So far uNocA did its best in this regard. It should be appreciated.

To transfer deminimg activities, from UNOCA to UNDF does not make any sence. By being a UN agency, UNoCA has the same treedom and ability to operate'the demining independently and

effectively. It is believed and experienced that UNDCA was neutral, js neutral and will be neutral. UNOCA shoula have the right to administer all functions relating Afghanistan, demining as we 11 .

b. It is obvious that demining Afghanistan will take more time than expected. None of the nation or UN can support this operation forever, by providing funds and national experts. Sooner or later this task is going to be done by Afghans themselves. Therefore, the present policy namely, multiple semiautonomous organizatioral system, is more favorable to hand over whole responsibilities and managements of demining operation to Atghans at any time.

A complete centralized command and control would be needed for the first $h b$ months or one year period of $t$ ime, to adopt swiftly Afgian deeming agencies to their job. Now, it is too late.

ance, after getting up speed in this way to go another direction namely, centraljzation of command and control may not help the future of demining operation.

On the other hand, no one can say that the whole demining operation were not being coordinated and cantrolled by UNOCA. Rs it is known that all directives and priorities dealing with the demining werelare being given by UNOCA, HQ.

It is not the best solution to advise ceasing MCPA and consolidating with DHO. Everybody knows that mCPA have provided considerable and adequate work for both ATC and SWAAD in aCcordance with the consolidated training thaught by the national experts from different countries under supervision of expatriate experts from differmnt nations.

To deploy survey teams with ATC, SWAAD and DHQ is not practical solution then at present. Lots of operational, logistical and administrative problems are to raise otherwise. 
It is fact that there is no rellable intelligence source such as mineflelds records and maps obtalned from USSR, central Government or Mujahideen.

Atghan conflict was not a conventional war. It was mostly Guerilla war and now, it is $\mathrm{mixture}$ of guerilla and civil war. This is the reason why that any map or plan showing minefields should not be accepted as an only reliable source. It is believed and was experienced that during war, anybody could deploy mines anywhere without precise record or any record. also, till now some mines had been picked up by the lofals for various reasons or the location of some mines had been changed by weather conditions. All these matters have made it difficult to find out the limits, composition and pattern of the mined arsas. Therefore, nobody can say there is mine here, no mine there. In these cases we are fully agreed that we should separate minetields into three categortes as mentloned in the evaluation report and should alve priorities according to categories. The main and the most reliable information source which MCPA has now, is questioning the local Shuras, commanders and common local people and reconnaigsance by eye and checting the suspected area by detector. From the very beginning MCFA have been collecting considerably detailed information in consultation with the local authorities, preparing required documents for each minefield as shown at ANNEXES- $A, B, C, D, E, F, G$, and $H$, disseminating to ATC and SWAAD in detali to Demining DHQ. in summary and Heeping the whole data in computerized technic.

Although these facts, it is not tair to state that MCPA has no data and recording system. What interesting is that the two evaluator did not pay visit to MCPA HQ both in Peshawar and Quetta to be briefed with sufticlent information. We are Mighiy worrying that how they can right down some statements either in tavor of MCPA or intavor of MCFA with no direct contact. It is impossible to find out that where these information were obtalned.

It is true that disseminating detalied information directly to ATC and SWAAD might cause HO to have lack of data. To enable DHQ to select working areas and priorlties and to control and command all demining activities, from now on, MCFA must send all information. directly to UNDCA, DHQ. for this purpose, it is recommended that the reporting system shown at annex-1 should be set up and the operation section statt in DHQ should be widened to enable HQ to prepare maps, charts, data base showing all results of the planing and cleaning activities. It will be very nelpful to provide extra fund to MCFA to carry out a country-wide seneral survey of mines in Afghanistan.

c. MCPA survey/monitoring teams has gained a lot of technical knowledge during one and half year period, they know the area better than any national. They can communicate with the people and deminer better than any national. Surveyor and deminer can understand each other easily these are the reasons that MCFA survey/monitoring teams should conduct monitoring as well. But, it should be conducted together with the experts for some time. 
d. The flail operation should continue. Ceasing flails one year from service is not logic. Logistical and administrative prablems should be solved in Afghanistan while the machines are working. Also, in such kind of report prepared for UN, it is important not to mention any person or country name, for some certain job.

e. it does not matter that ight vehicles and nearly 70 man at wort in the small valley. What important is to demine the area where local people could not use due to the tearing of mines. The main objective of the demining in Atghanistan is to give confidence to the local people. One should recognize that. there are hardly roads following standard route in Atghanistan. Most of the river beds are used as a line of communication. Again, one should recognize that there are hardly irrigated lands in Atghanistan. Now and then, the ory land is important as much as irrigated land in Atghanistan. No matter the villages are far away from the minefields. No one can force the people to jive just in the certain and 1 imited area. They have and will have the right to traval and to use any land part. The areas where people are moving and using must be checked. It does not matter how big or how small is.

Any life of human can not be paid by money. It is not matter that a mine would cost $\$$. 1000 . Success of the demining operation should not be measured with the number of mines found but should be measured with the area cleaned.

In all these regards, recently an interview was done by Eng. Zabihuldah Supervisor MCPA Quetta with SWAAD deminers and $100 a 15$. some of these interviews can be seen at ANNEX-K. One can realized that it is different from the point of view of the evaluation report.

4. It is sure that the presence of mines was the principle deterrent to the return of refugees. At the beginning of this programme and as a contact agency with the Shura, commanders and people in Afghanistan we were strongly told so. But, they were expecting a switt political settlement parallel to demining operation as well. The tuture of Atghanistan is still vogue and unsafe due to onsoing contlicts. It is necessary to understand that this is not fault of the demining operation. Once, political settlement reachad, the refugees will return to the demined areas but not mined areas.

9. As it is known, efforts of the demining programme is not limited to three provinces, to Pushton or Fathans area. Demining operation have been extended not only to Kandahar. Paktia, Konar or Fathans area but also anywhere in Ghaznj, Faktika, Zabul, Helmano, Nimroz, Bamyan, Badakshan, Badgtis and Nengarhar as situation permit.

h. It is quite obvious that demining can not be done without training. Therefore, ther was no other option for the first senior programme manager oxcept emphasizing training.

Nevertheless, at the time of first programme manager, during programme had been started at the village level in Afghanistan is recommailed by evaluators. 
But, it was impossible to control the operation and to support logistically. All demining kits which were given to a 3 man village deminer team, either sold or captured or used for other purposes. Then, it was given up. Due to unsafe and vague situation in afghanistan now, it is believed that village level demining operation is not possible. One should imagine how big organization need to manage the viliage level demining operation. Such operation, may be, cause demining operation to stop.

After ceasing village level demining programme, it was discussed to find better solution and decided to conduct in professional manner. Then present system was set. This aldaw all demining agencies to control and command their functions easily. The sacond, present senior programme manager have improved, rectified and supported the whole programme.

i. Demining operation is difficult and dangerous work. It needs good discipline. It needs to employ those who know importance of the mine and those who know what command, control and discipline are. These are the reason why, to the contrary of the evaluators, we are favor of ATC employing military or paramilitary personnel.

k. Normally, both ATC and SWAAD may regularly receive request from local authorities requesting the demining agencies to clear mined areas. In any condition these requests had to be forwarded to MCPA. Demining unsurveyed area is an indication of lack of the discipline. It is recommended that from now on, all requests obtained by ATC or SWAAD must be torwarded to MCPA or DHQ.

1. With the nearly two years technical and practical experience, all demining agencles gained ability how to train as well it is believed that when training need all demining agencies can manage to train their teams, therefore, there is no need to heep Resalpur training camp open.

m. The relation between MCPA and other demining agencies is absolutely satisfactory. Without good relation such amount of wark would not be done.

n. General polley of demining operation will be determined by DHQ. Demining agencies will have to do the same. Theretore, each agency needs no separate steering committee. It is strongly believed that a central, strong and high quality staering committee at the DHQ will be practical and economic.

\section{CONCLLUSION}

It is bolieved that two evaluators have done good job in some extent. But it is fict that the ongoing demining operation programme which was set and created by the idea of hundreds of national or international expert and a lot of Afghan intellectual in two years experience and challenges, should not be allowed to be ruined by two evaluators who had no enough experience on the project other than a 15 day period of time. 1 t is easy to show the way what to do. But it is not easy for him/her to do what he/she is advising to do. 
One of us, may be, can prepare better report on this matter than them.

No need to be pessimistic. We should heep our belief that we know better how to hand le this programme than anybody else. But, we should cansider and accept yood advice as well. We believe that this programme will not collapse but will improve and rectify.

Regards.

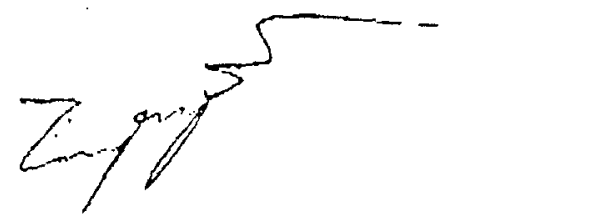

Zabihullah

Supervisor MCPA Quetta.

\section{ANMEXES:}

ANNEX-A : General location map. ANNEX-B : Summary of the minefielos. ANNEX-C : Main report for minefield. ANNEX-D : Brisf repart for minefield. ANNEX-E : Summary report for minefield. ANNEX-F : Sketch map of the minefield. ANNEX-G : Photolog for minefield. ANNEX $-H$ : Status report. ANIVEX-I : Command and control system. ANNEX-K : Interview with deminers. 


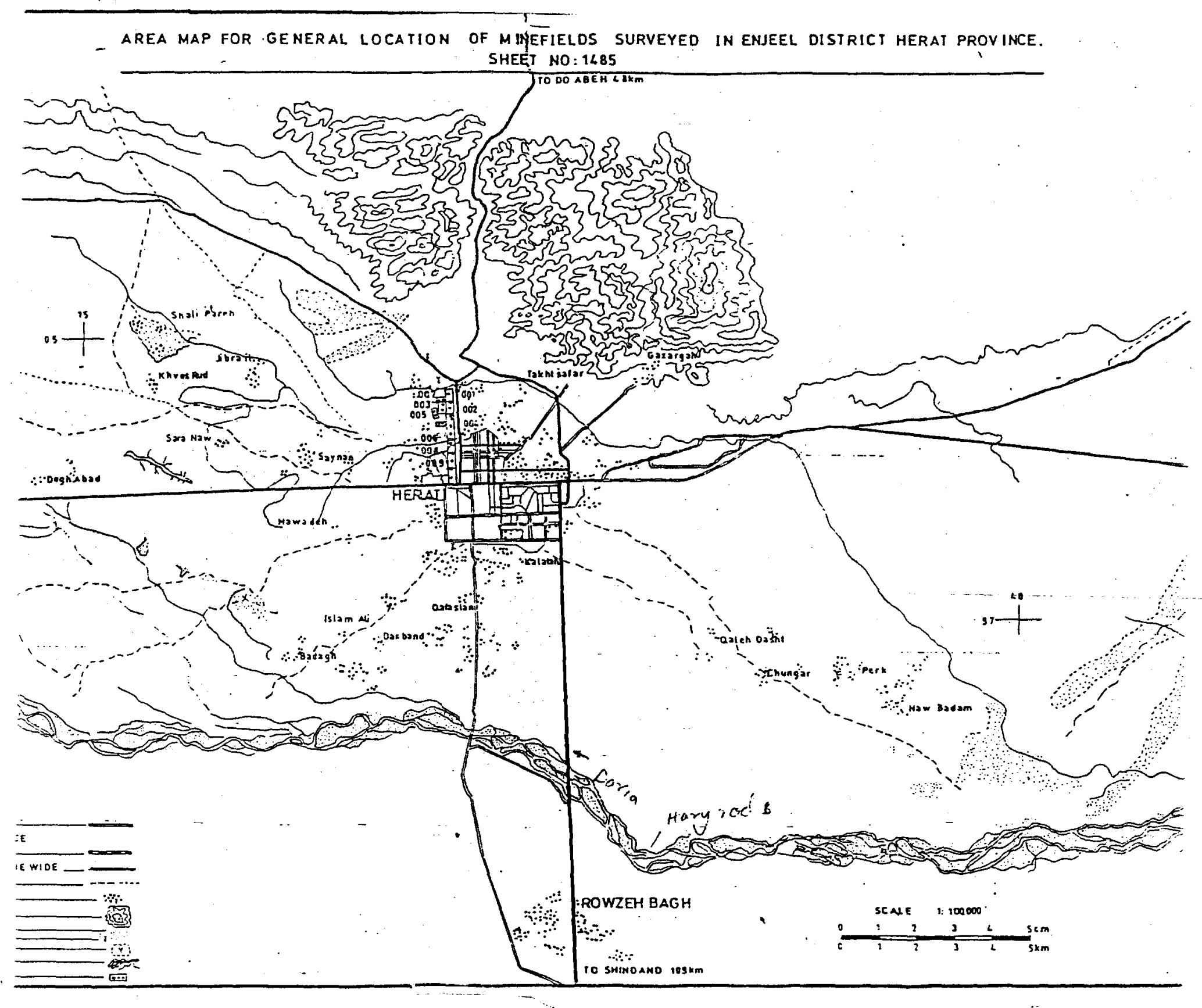

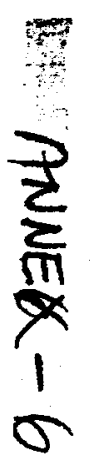




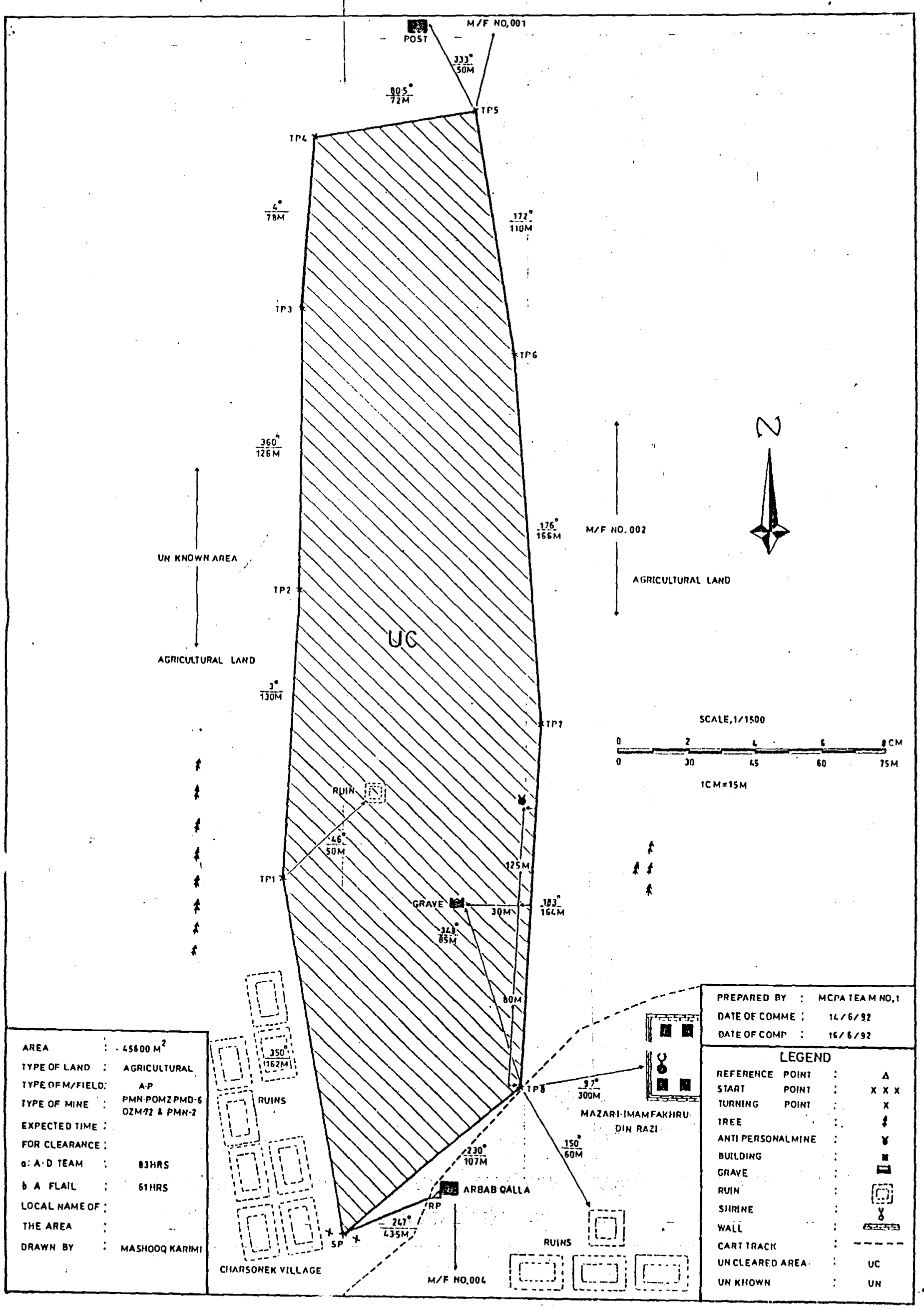


PROVINCE CODE NO、20/2002/37/002

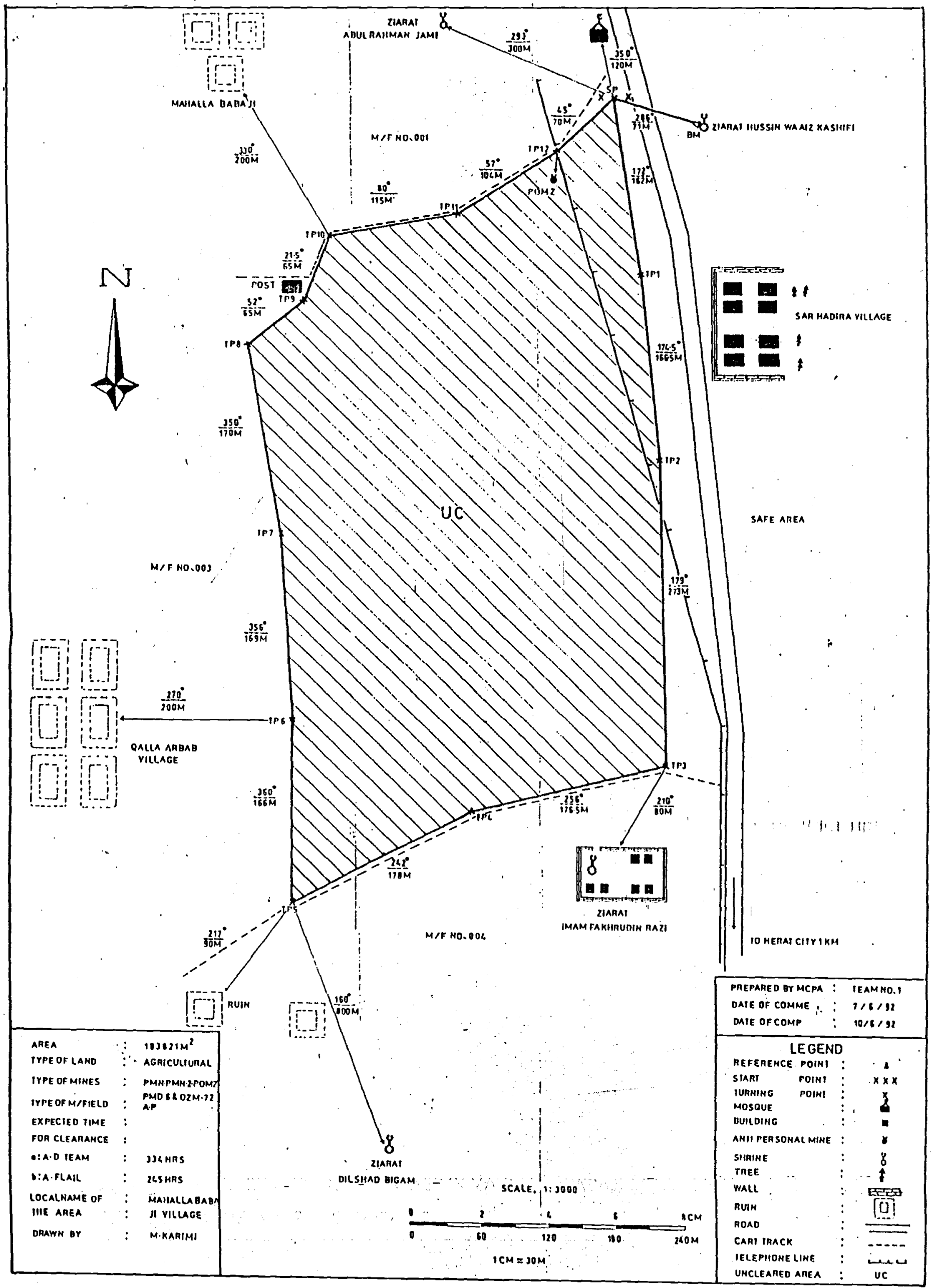


SKETCH MAP OF MINEFIELD N0.001 SURVEYED IN MAHALA-I-BABA JI VILLAGE ENJEEL DISTRICT HERAT PROVINCE

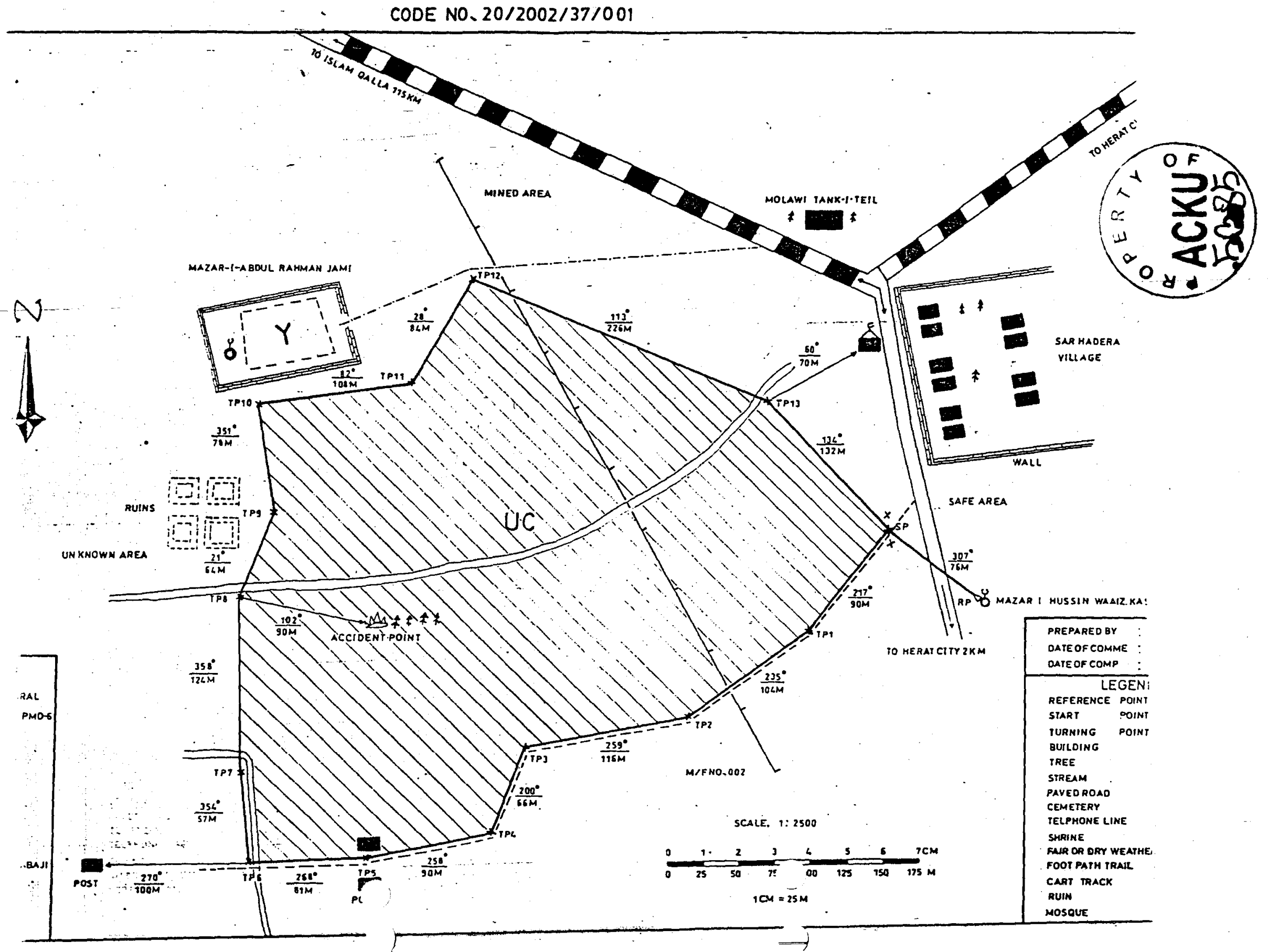

